\title{
Drinking Water Quality Status and Contamination in Pakistan
}

\author{
M. K. Daud, ${ }^{1,2}$ Muhammad Nafees, ${ }^{3}$ Shafaqat Ali, ${ }^{4}$ Muhammad Rizwan, ${ }^{4}$ \\ Raees Ahmad Bajwa, ${ }^{3}$ Muhammad Bilal Shakoor, ${ }^{3}$ Muhammad Umair Arshad, ${ }^{5}$ \\ Shahzad Ali Shahid Chatha, ${ }^{6}$ Farah Deeba, ${ }^{2}$ Waheed Murad, ${ }^{7}$ \\ Ijaz Malook, ${ }^{2}$ and Shui Jin Zhu' \\ ${ }^{1}$ Department of Agronomy, College of Agriculture and Biotechnology, Zhejiang University, Zijingang Campus, \\ Hangzhou 310058, China \\ ${ }^{2}$ Department of Biotechnology and Genetic Engineering, Kohat University of Science and Technology, Kohat 26000, Pakistan \\ ${ }^{3}$ Institute of Soil \& Environmental Sciences, University of Agriculture, Faisalabad, Faisalabad 38040, Pakistan \\ ${ }^{4}$ Department of Environmental Sciences and Engineering, Government College University, Allama Iqbal Road, \\ Faisalabad 38000, Pakistan \\ ${ }^{5}$ Institute of Home and Food Sciences, Government College University, Faisalabad, Pakistan \\ ${ }^{6}$ Department of Applied Chemistry, Government College University, Faisalabad, Pakistan \\ ${ }^{7}$ Department of Botany, Kohat University of Science and Technology, Kohat 26000, Pakistan
}

Correspondence should be addressed to Shafaqat Ali; shafaqataligill@yahoo.com and Shui Jin Zhu; shjzhu@zju.edu.cn

Received 4 February 2017; Accepted 14 May 2017; Published 14 August 2017

Academic Editor: Masood Ahmad

Copyright (C) 2017 M. K. Daud et al. This is an open access article distributed under the Creative Commons Attribution License, which permits unrestricted use, distribution, and reproduction in any medium, provided the original work is properly cited.

\begin{abstract}
Due to alarming increase in population and rapid industrialization, drinking water quality is being deteriorated day by day in Pakistan. This review sums up the outcomes of various research studies conducted for drinking water quality status of different areas of Pakistan by taking into account the physicochemical properties of drinking water as well as the presence of various pathogenic microorganisms. About $20 \%$ of the whole population of Pakistan has access to safe drinking water. The remaining $80 \%$ of population is forced to use unsafe drinking water due to the scarcity of safe and healthy drinking water sources. The primary source of contamination is sewerage (fecal) which is extensively discharged into drinking water system supplies. Secondary source of pollution is the disposal of toxic chemicals from industrial effluents, pesticides, and fertilizers from agriculture sources into the water bodies. Anthropogenic activities cause waterborne diseases that constitute about $80 \%$ of all diseases and are responsible for $33 \%$ of deaths. This review highlights the drinking water quality, contamination sources, sanitation situation, and effects of unsafe drinking water on humans. There is immediate need to take protective measures and treatment technologies to overcome unhygienic condition of drinking water supplies in different areas of Pakistan.
\end{abstract}

\section{Introduction}

Pakistanis are situated in southern Asia, bordering with India in the east, Afghanistan in the west, and China in the north. In the east of Pakistan, there exist mountains of Himalaya and Karakorum. In the north, Hindukush ranges exist, and hill regions (up to $4700 \mathrm{~m}$ ) in the northwest and in the upland Baluchistan plateau exist. The climatic conditions are mostly arid to semiarid with varying levels of average rainfalls in different areas of Pakistan [1]. Indus is the major river of Pakistan, flowing from Karakorum ranges to south and finally falls in the Arabian Sea. Agriculture farming has a major role in Pakistan's economy. 27\% of the total land is under farming and the main crops are wheat, maize, rice, cotton and sugarcane. To fulfill the requirements of increasing population, pesticides, and fertilizers are applied to increase the crops outcome. Most of industries such as textile, pesticide, and fertilizer industries are present in major cities.

Pakistan has been blessed by nature with enough surface and groundwater resources. Industrialization, urbanization, and rapid population growth have placed huge stress on water resources [2]. Water has a vital role in our life processes 
including growth and development. It plays significant role in our every field of life [3]. Due to technological developments, drinking water may contain various impurities, which are of physical, biological, and chemical nature. The most dangerous impurity is of biological nature, which causes human health problems or cause death [4]. Various impurities in the form of nutrient and microorganisms are transported from one place to another [5]. Water pollution occurs when microorganisms and toxic chemicals from domestic waste and industries either come in contact with water bodies or run off or leach into ground water or freshwater resources [6]. The contamination of animal and human fecal indicates presence of coli form bacteria [7]. The growth and dispersion of bacteria is at peak in rainy season due to drainage in water bodies, that is, rivers, lakes, and streams. Poor treatment facilities cause spread of waterborne diseases. In Pakistan, drinking water sanitation system and drainage lines run in parallel, which causes leakages and intermixing result in deterioration of water quality [8].

In most of the cities of Pakistan, the elementary source of provision is ground water supply, which contains various pathogens including many viral, bacterial, and protozoan agents causing 2.5 million deaths from endemic diarrheal disease each year [9].

Water pollution is a physical process that occurs in various water resources such as lakes, ground water, and rivers due to anthropogenic activities [10]. The utilization of poor quality water causes waterborne diseases and their spread. In Pakistan, about $50 \%$ of diseases and $40 \%$ of deaths occur due to poor drinking water quality reported in community health studies [11]. Above $80 \%$ of the people of province of Khyber Pakhtunkhwa (KP) are utilizing clean drinking water that comes from surface and ground sources. In KP, surface water resources are clean and fit for drinking but, in the south, color of ground water is blackish. Clean water is also found in deepness. But, in the center of KP ground water availability is excessive and pumped out with the help of tube wells for routine use. The water resources in the north of KP are mainly surface water resources and springs. The drinking water quality and quantity are very low because of poor treatment of deteriorated water and old sanitation system in urban areas [12].

When water comes from surface water resources, it is necessary to make it safe for drinking purposes. Chlorination is the popular method for disinfection of drinking water at treatment plant and in sanitation system [35]. It is the universal method to make drinking water safe and to reduce epidemic diseases [36-39].

Drinking water should be free from color, turbidity, odor, and microbes. It should be esthetically pleasant. Due to increasing population of Faisalabad, contaminated water is the most alarming problem. In 1999, Faisalabad required about 64.7 million gallons of drinking water supply daily to fulfill needs. But unfortunately 3 million gallons of this water came from domestic pumps that come out from subsoil water and tube well [40]. According to Pakistan National Conservation Strategy [41], less rain, drought, and nondevelopment of other water resources reduce water availability and increase water scarcity.
The current water supply is about 79\% in Pakistan [42]. Improper and poor water supply for drinking purpose has a great health risk to the public. The release of toxic chemicals from urban communities and industries without any treatment into water bodies deteriorates water quality and also causes adverse effects to human beings. In Pakistan, water and sanitation agency has been focusing on water quantity due to increasing requirements rather than water quality. All this is due to the lack of awareness, treatment technology, equipment, trained personnel, and quality monitoring [43].

Human health is adversely affected by various agents like pathogens, bacteria, various minerals, and organic substances that are present in unsafe drinking water. A significant proportion of population in developing countries is suffering from health-related issues due to unsafe drinking water and microbial contamination [44]. In the developing countries, about five million children deaths occurred due to the contaminated drinking water supply [45]. This situation is intensifying day by day due to the fast population growth which ultimately results in poor management of water quality [46]. It is estimated that, in Pakistan, 30\% of all diseases and $40 \%$ of all deaths are due to poor water quality [47]. Diarrhea, a waterborne disease, is reported as the leading cause of death in infants and children in Pakistan while every fifth citizen suffers from illness and disease caused by the polluted water [48].

In Pakistan, approaches to safe drinking water have reached acceptable limits. Reference [49] analyzed that about $25 \%$ population has approach to safe drinking water. The poor water supply was caused by the lack of water availability. Water pollution is mainly caused by heavy utilization of water for domestic, agricultural, and industrial purposes.

In Pakistan, the main reasons of waterborne diseases in drinking water are the addition of municipal sewage and industrial wastewater at different points of the water distribution network as well as lack of water disinfection and water quality monitoring at treatment plants. Pakistan National Conservation Strategy [41] reported that water-related diseases represent $40 \%$ of the communicable diseases. In Pakistan, waterborne diseases are typhoid, giardiasis, intestinal worms, diarrhea, cryptosporidium infections, and gastroenteritis. Infant deaths caused by water-related diarrhea are $60 \%$ in Pakistan according to International Union on Conservation of Nature (IUCN) report, which is the highest ratio in Asia.

In Pakistan, water quality in most of the cities is decreasing quickly. The major cause of decreasing water quality is the ground water supply. According to [50], the number of diarrheal cases that are registered in Pakistan each year is about one hundred million. According to Tahir et al. [51], above eighty thousand cases related to waterborne diseases were noted in healthcare units only in Rawalpindi. 20\%-40\% of hospitals of Pakistan are filled with people that are suffering from waterborne illness, according to United Nation International Children Emergency Fund (UNICEF). Diseases such as cholera, typhoid, dysentery, hepatitis, giardiasis, and cryptosporidiosis and guinea worm infections represent about $80 \%$ (including diseases due to sanitation problem) of all diseases and are responsible for 33\% of deaths [51]. 


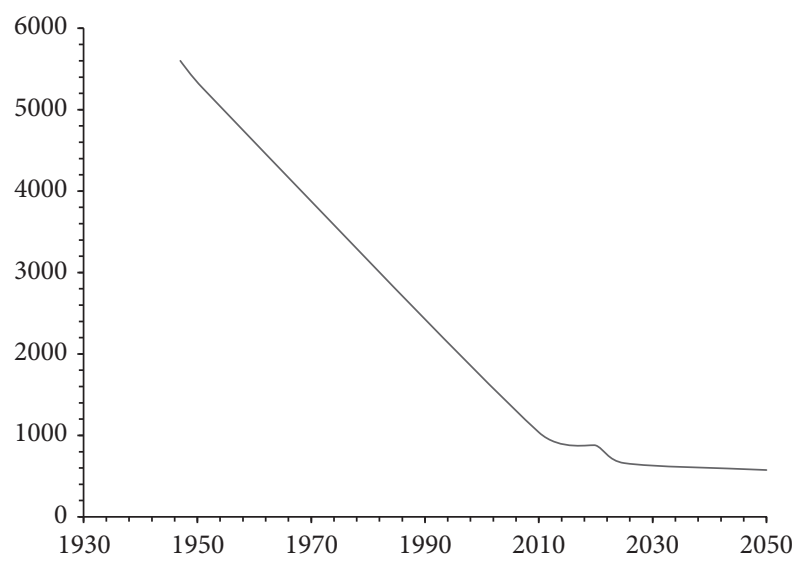

FIGURE 1: Per capita water availability decreasing tremendously in Pakistan.

\section{Water Availability}

Nature has gifted Pakistan with enough ground and surface water resources. Unfortunately anthropogenic activities such as industrialization, increase in population, and improper utilization decrease the quantity and damage the quality. According to Jamshed Iqbal Cheema (Chairman: Pakistan Agriculture Scientists Association), the per capita water availability in Pakistan at the time of independence was 5,600 cubic meters [52], which has been decreased by over 406 percent from 5,260 cubic meters in 1951 to 1,038 cubic meters in 2010. If the status quo continues, then, by 2020, the water availability in Pakistan will further plummet to 877 cubic meters per annum and will further decrease to 660 by year 2025 and will further go down to an alarming level of 575 cubic feet in 2050 [53] (Figure 1).

In Punjab, $7 \%$ of all the rural population depends on dug wells and rivers for water supply. It seems that Punjab has best water supply system among all the provinces. This ratio is $24 \%$ in Sindh and people are utilizing water from unprotected sources. The rural communities of Khyber Pakhtunkhwa (KP) and Baluchistan using water from surface and dug well are about $46 \%$ and $72 \%$, respectively, [1], as shown in Figure 2.

\section{Water Quality}

Water for drinking purposes mainly comes out from the surface and underground aquifers near the rivers or canals. The surface water quality is dropping rapidly due to the addition of raw municipal and industrial effluents and agriculture runoff into water resources [54]. When flow of river water is at its peak, it contains high solid suspension. Most of the rivers are extended and diluted and do not endure aquatic life. It is clear that these water bodies are fecally contaminated and need proper processing to free them from contaminants for human use. In Pakistan, four major cities have been using surface water; these are Islamabad, Karachi, Rawalpindi, and Hyderabad.

About $70 \%$ of water for drinking purposes comes from aquifers [55]. The decrease in ground water quality is due

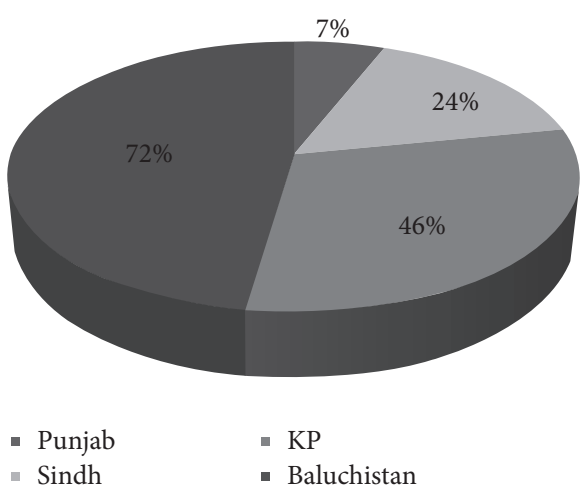

FIGURE 2: Dependence of water supply in the provinces of Pakistan.

to the overpumping of saline water and its addition to fresh water. The ground water quality in Pakistan is found saline far away from the main rivers and fresh water near to the main rivers. The quality of drinking water is determined by the quality of water source, the level and treatment efficiency, and condition of water supply lines. In Pakistan, in most areas where the fresh water source is not available and ground water is saline, people have no choice but to use this type of water for drinking. The contamination of water due to microbes is the most blistering issue. The drinking water distribution in urban areas does not meet the WHO standards [56]. The main reason of microbial contamination is due to the intermixing of sewer lines with drinking water supply lines. In most of the rural areas of Pakistan, surface water is used for drinking after slow sand filtration and chlorination is not done at filtration stations. In most rural areas, no pretreatment facilities are available for filtration of water. All this inadequacy is due to microbial contamination and poor water quality. Hand pumps and wells are not safe from surface runoff and flooding [57].

Water pollution is the deterioration of water quality due to the addition of wastes coming from industries, domestic and agriculture. Utilization of such water for beneficial use causes contrary effects on environment and public health. Industrialization and emergence of urban units placed immense stress on water resources and discharge of wastewater into natural water resources that decreases ground and surface water quality [58].

The most serious pollutants in terms of human health worldwide are pathogenic organisms. Altogether, at least 25 million deaths each year occur due to these water-related diseases, including nearly two-thirds of the deaths of children under five years of age. The main and major source of biological agents is unprocessed and unconventional treatment of human waste [59]. The highest infant mortality rate $(12.6 \%)$ and fertility rate $(7 \%)$ reflect the poor health status of Pakistan. The bare hospital information indicates that most of the treated diseases are due to fecal contamination. About $25 \%$ of patients treated at hospitals, private clinics, or healthcare centers are suffering from diarrhea including children and adults $[60,61]$. 


\section{Water Quality Parameters}

The physical, biological, and chemical properties of drinking water have great importance because a minor fluctuation in these parameters affects the human health. The $\mathrm{pH}$ is crucial factor that greatly affects water quality and quantity of pollution in water bodies [62]. However, $\mathrm{pH}$ of drinking water has no direct effect on human. Indirectly it changes meat solubility and provides suitable environment for pathogens. High $\mathrm{pH}$ causes acidic taste of drinking water [63]. The defined standards of drinking water quality [64] are shown in Table 1.

\section{Sources of Contamination}

5.1. Microbiological Contaminants. In Pakistan, microbial pollution has been discovered as one of the serious problems in rural as well as urban areas. This is due to the leakage of pipe, pollution from sewage lines intrusion into drinking water supplies, and so forth.

5.2. Chemical Contaminants. Chemical contaminants come from industries, soil sediments, and runoff from agriculture, that is, pesticides and fertilizers, and enter into water resources. In Pakistan, the application of fertilizer and pesticides is, respectively, about 5.6 million tons and 70 thousand tons according to Gross Operating Profit (GOP) figures. These chemicals, commonly insecticides, leach into ground water resources by mixing with irrigated and rain water. During 1988-2000, about 107 samples were collected from ground water and 31 samples indicated pesticide contamination that was clearly beyond the Food and Agriculture Organization (FAO) and WHO permissible limits. In Pakistan, another important trouble with ground water is highest concentration of salts, which is mainly due to irrigation, soil salts dissolution, sea water encroachment, and chemical industries. Salinity impacts the major areas of Baluchistan, KP, and Punjab. Effluent from industries and domestics contains high concentration of arsenic that is becoming a severe problem. In major cities of Sindh and Punjab, about sixteen percent of people are exposed to more than $50 \mathrm{ppm}$ of arsenic. Higher concentration of fluoride above permissible limits causes a trouble in major areas of Baluchistan, Punjab, and Sindh. The dental fluorosis diseases are commonly found in Sindh, Punjab, and KP.

\section{Floods Cause Major Damage to Drainage System}

In Pakistan, floods have been creating great environmental problems. They damage drains and ultimately cause spillage of sewage water into water bodies. Severe flooding destroys buildings and standing crops. All these may cause release of toxic chemicals and oil into river, streams, and lakes, and so forth and may lead to death of aquatic life. A lot of chemical contaminants mix with flood water on its way. The current severe flood (2010) and heavy rains damaged $80 \%$ of Nowshera, devastating $40 \%$ of infrastructure. The total destroyed and damaged houses were in the range of 10,000 and 40,000, respectively [65].

\section{Water Quality Status in Provinces of Pakistan}

7.1. Water Quality Status in Twin Cities. To evaluate the drinking water quality of Islamabad, drinking water samples had been collected from schools and colleges. Analysis showed that 20 samples out of 30 were contaminated with fecal microbes and not fit for drinking purposes [66]. Microbial contamination is the most common and widespread risk associated with drinking water. About 130 samples were collected from nine areas to analyze microbial contamination in drinking water of Rawalpindi and Islamabad. $56.1 \%$ of water samples were found to have microbial contamination. Microbial contamination for fecal coliforms, E. coli, and total coliforms was $23.8 \%, 20 \%$, and $12.3 \%$, respectively. The WASA supply lines were highly contaminated followed by capital development authority lines and boring water and less contamination was found in tanker water [16], while thirtytwo samples were collected from different water filtration plants throughout Islamabad city and it was found that more than half of the samples were contaminated with total coliform, fecal coliform, and E. coli [18].

Geographic Information System and Water Quality Index study of bore wells and open wells of Rawalpindi and Islamabad revealed that more than half of samples were poor in quality for drinking due to overexploitation of groundwater resource, agricultural impact, and direct release of contaminants [15].

Drinking water contamination with E. coli and fecal coliforms is clear indication of human and animal waste intervention [67]. In Rawalpindi, water distribution channels and treatment plants were also having fecal coliform contamination $[67,68]$. The Rawal Lake and its distributions channels are the main source of drinking water for Rawalpindi, which were also found highly contaminated with bacteria [69]. Water quality of Islamabad was analyzed by [13]. Results obtained showed that about $77 \%$ of the total 271 samples collected were biologically contaminated and unfit for human use. On the other hand $10.3 \%$ of the total samples were found to be physically and also biologically contaminated, among which 196 samples from capital development authority (CDA) were collected for drinking water analysis. The result showed that $5.1 \%$ of the total samples collected were found to be bacteriologically contaminated and 3.6\% were found to be both physicochemically and bacteriologically contaminated. In Islamabad and Rawalpindi, the water quality was not found better than the whole country. The water quality of natural streams situated in the capital city is also deteriorated. Water reservoirs were highly contaminated with total coliform and fecal coliforms bacteria, so proper water treatment for drinking and domestic use is required [70]. The heterotrophic bacterial assessment of drinking water quality of tube wells, water supplies, and filtration plants in various sectors of Islamabad revealed that $21 \%$ of 55 samples were contaminated with total coliform, fecal coliform, and E. coli [17].

Physicochemical parameters on water quality of Islamabad indicated that alkalinity, hardness, and total dissolved solids in all samples were within safe limits as recommended by Pakistan Standard and Quality Control Authority 
TABLE 1: National Standards for Drinking Water Quality.

\begin{tabular}{|c|c|c|}
\hline Parameters & Standard values for Pakistan & WHO standards \\
\hline \multicolumn{3}{|c|}{ Biological } \\
\hline $\begin{array}{l}\text { All water intended for drinking (E. coli or } \\
\text { thermotolerant coliform bacteria) }\end{array}$ & Must not be detectable in any $100 \mathrm{~mL}$ sample & Must not be detectable in any $100 \mathrm{~mL}$ sample \\
\hline $\begin{array}{l}\text { Treated water entering the distribution } \\
\text { system (E. coli or thermotolerant coliform } \\
\text { and total coliform bacteria) }\end{array}$ & Must not be detectable in any $100 \mathrm{~mL}$ sample & Must not be detectable in any $100 \mathrm{~mL}$ sample \\
\hline $\begin{array}{l}\text { Treated water in the distribution system }(E . \\
\text { coli or thermotolerant coliform and total } \\
\text { coliform bacteria) }\end{array}$ & $\begin{array}{l}\text { Must not be detectable in any } 100 \mathrm{~mL} \text { sample } \\
\text { In case of large supplies, where sufficient } \\
\text { samples are examined, it must not be } \\
\text { present in } 95 \% \text { of the samples taken } \\
\text { throughout any } 12 \text {-month period }\end{array}$ & $\begin{array}{l}\text { Must not be detectable in any } 100 \mathrm{~mL} \text { sample } \\
\text { In case of large supplies, where sufficient } \\
\text { samples are examined, it must not be } \\
\text { present in } 95 \% \text { of the samples taken } \\
\text { throughout any } 12 \text {-month period }\end{array}$ \\
\hline \multicolumn{3}{|c|}{ Physical } \\
\hline Color & $\leq 15 \mathrm{TCU}$ & $\leq 15 \mathrm{TCU}$ \\
\hline Taste & None & None \\
\hline Odor & None & None \\
\hline Turbidity & $<5 \mathrm{NTU}$ & $<5 \mathrm{NTU}$ \\
\hline Total hardness as $\mathrm{CaCO}_{3}$ & $<500 \mathrm{mg} / \mathrm{L}$ & - \\
\hline TDS & $<1000$ & $<1000$ \\
\hline$\underline{\mathrm{pH}}$ & $6.5-8.5$ & $6.5-8.5$ \\
\hline \multicolumn{3}{|c|}{ Chemical } \\
\hline Essential inorganic & $\mathrm{mg} / \mathrm{L}$ & $\mathrm{mg} / \mathrm{L}$ \\
\hline Aluminum $(\mathrm{Al}) \mathrm{mg} / \mathrm{L}$ & $\leq 0.2$ & 0.2 \\
\hline Antimony $(\mathrm{Sb})$ & $\leq 0.005(\mathrm{P})$ & 0.02 \\
\hline Arsenic (As) & $\leq 0.05(\mathrm{P})$ & 0.01 \\
\hline Barium (Ba) & 0.7 & 0.7 \\
\hline Boron $(B)$ & 0.3 & 0.3 \\
\hline Cadmium (Cd) & 0.01 & 0.003 \\
\hline Chloride $(\mathrm{Cl})$ & $<250$ & 250 \\
\hline Chromium (Cr) & $\leq 0.05$ & 0.05 \\
\hline Copper $(\mathrm{Cu})$ & 2 & 2 \\
\hline Toxic inorganic & $\mathrm{mg} / \mathrm{L}$ & $\mathrm{mg} / \mathrm{L}$ \\
\hline Cyanide $(\mathrm{CN})$ & $\leq 0.05$ & 0.07 \\
\hline Fluoride $(\mathrm{F})^{*}$ & $\leq 1.5$ & 1.5 \\
\hline Lead $(\mathrm{Pb})$ & $\leq 0.05$ & 0.01 \\
\hline Manganese (Mn) & $\leq 0.5$ & 0.5 \\
\hline Mercury (Hg) & $\leq 0.001$ & 0.001 \\
\hline Nickel (Ni) & $\leq 0.02$ & 0.02 \\
\hline Nitrate $\left(\mathrm{NO}_{3}\right)^{*}$ & $\leq 50$ & 50 \\
\hline Nitrite $\left(\mathrm{NO}_{2}\right)^{*}$ & $\leq 3(\mathrm{P})$ & 3 \\
\hline Selenium (Se) & $0.01(\mathrm{P})$ & 0.01 \\
\hline Residual chlorine & $0.2-0.5$ at consumer end, $0.5-1.5$ at source & - \\
\hline Zinc $(\mathrm{Zn})$ & 5.0 & 3 \\
\hline \multicolumn{3}{|c|}{ Organic } \\
\hline Phenolic compounds (phenols) mg/L & & $\leq 0.002$ \\
\hline Polyaromatic hydrocarbons (PAH) g/L & & 0.01 (by GC/MS method) \\
\hline
\end{tabular}

* indicates priority health related inorganic constituents which need regular monitoring. 
(PSQCA). But coliform and E. coli were detected in all water samples, so water was found unfit for drinking purposes as WHO recommended [14]. Higher amount of calcium, lime stone, and magnesium carbonate in drinking water caused significant level of hardness in I-9 and G-10 sectors, in Islamabad [71]. E. coli was detected in drinking water samples collected from Risalpur, Pabbi, and Tarnab [72] as shown in Table 2 .

7.2. Water Quality Status in Punjab. Drinking water quality and chlorination effect of two villages in south Punjab were analyzed [73]. Results of this study highlighted that all 53 samples collected from two villages had significant numbers of $E$. coli bacteria before and after chlorination process. According to WHO and PEPA, drinking water should contain $0 / 100 \mathrm{~mL}$ of $E$. coli or coliform.

Faisalabad is known as polluted industrial city due to the inadequate treatment facilities. The impact on water resources near Samundri drain in Faisalabad showed that the ground water quality was the worst as $90 \%$ of samples were above the WHO limits with respect to TDS, $\mathrm{Na}, \mathrm{K}, \mathrm{Cl}$, and $\mathrm{SO}_{4}$ [21]. The people's perception of rural areas in a tehsil Samundri, district Faisalabad, was that the water quality of different sources, that is, hand and electric pumps, was poor [26].

The physicochemical analysis of drinking water was carried out to evaluate drinking water quality of Faisalabad city. The turbidity, hardness, $\mathrm{pH}$, and TDS were found within safe limits of WHO guidelines. The microbial analysis showed that all samples were contaminated with total coliforms and E. coli [22]. The impact of municipal and industrial wastewater on water resources in Faisalabad showed that the physicochemical properties of ground water were beyond the critical values of WHO. However, bottle and supply lines were within critical range [20].

Chemical and biological analyses of drinking water samples collected from three different sites in Faisalabad showed that $\mathrm{pH}$ was found within the range according to $\mathrm{WHO}$ standards and electrical conductivity was found above the permissible limits. Higher electrical conductivity (EC) is due to the dissolution of subsoil minerals and leaching into ground water. Bacteria were also found in water samples which showed fecal contamination. All these analyses indicate that water is not fit for drinking purposes [74]. The concentration of As and coliform bacteria was above the threshold level in samples collected from different sources in University of Punjab, Lahore [19].

Water quality monitoring was carried out to access chlorination of supply lines in Cantonment area, Rawalpindi. The temperature of all samples was above the critical values as recommended by WHO. Water temperature is an important factor for microbial growth [75]. The $\mathrm{pH}$ and total dissolved solids are within range of US-EPA and WHO limits and similar to the results of [68]. Conductivity and chlorine residuals were also found within limits of WHO. Total dissolved solids and conductivity have a direct relation: as concentration of mineral salts increases, conductivity increases [76]. Microbial analysis indicated the presence of fecal coliform in all samples collected from both sites [77].
Drinking water quality of urban areas of southern Lahore was evaluated before and after monsoon season. It was seen that the values of $\mathrm{pH}$ of all sources and house connections were well within the WHO desirable limit both before and after the monsoon season. The turbidity in water was less than the desirable limit of 0.5 NTU while it was more than 0.5 NTU before and after the monsoon at two sites. The hardness at all the sources (T/W) and house connections was less than the WHO guideline. The TDS values were in critical limits. The bacteriological contamination was also not detected in water samples before and after monsoon. Fecal contamination showed that water had come in contact with human feces [78].

Drinking water quality test carried out in twelve districts of Punjab showed that microbial and heavy metal (arsenic) were major contamination found in all districts. At least $45 \%$ of the samples of Kasur district were found to be contaminated with microbes. About 73\%, 100\%, 64\%, 94\%, 100\%, and $88 \%$ of drinking water samples of Sheikhupura, Lahore, Gujranwala, Multan, Kasur, and Bahawalpur were highly contaminated with arsenic. Total dissolved solids (TDS) were found above the permissible limits in Sargodha, Sheikhupura, Kasur, Faisalabad, and Rawalpindi [2]. Physical parameters of the samples collected from three different sites in Sabzazar district, Lahore, were within permissible limits of WHO. There was no detection of fecal coliform bacteria in samples collected from tube well and supply lines but E. coli contamination was detected in samples collected from household tabs showing that water was unfit for drinking purpose [79].

The chemical analysis of groundwater samples collected from rural areas of Punjab indicated that water was unfit for drinking purpose. High values of $\mathrm{EC}, \mathrm{Cl}^{-}, \mathrm{NO}_{3}{ }^{-}, \mathrm{SO}_{4}{ }^{2-}, \mathrm{Fe}$, $\mathrm{Mn}$, and $\mathrm{Pb}$ were observed in many samples above the permissible limits [80]. The poor drainage system and improper waste dumping in villages of Pakistan are the main source of drinking water contamination. The bacterial analysis of drinking water samples of tube well, hand pumps, and turbines from Gangapur (village), Faisalabad, had a clear image of cow dung and municipal waste water contamination causing stomach diseases, that is, diarrhea, especially in infants [81].

The physicochemical analysis of different samples collected from urban areas of Faisalabad showed that the $\mathrm{pH}$ value and hardness were within range as recommended by WHO. The values of alkalinity, TDS, sulphate $\left(\mathrm{SO}_{4}\right)$, and chlorides were found above the permissible limits of WHO. Overall the ground water used for drinking purpose in urban areas of Faisalabad was intensively polluted with sewerage water [82] as shown in Table 3.

7.3. Water Quality Status in Khyber Pakhtunkhwa (KP). Water samples were collected from tube wells and storage tanks to determine the drinking water quality in rural areas of Peshawar. Results indicated that just $13 \%$ of the samples were negative for bacterial contamination, $40 \%$ were found in the satisfactory level, and $47 \%$ of the samples were found to be highly contaminated with E. coli [83]. The physicochemical analysis of drinking water samples collected from thirty different sites across urban areas of Peshawar described that 


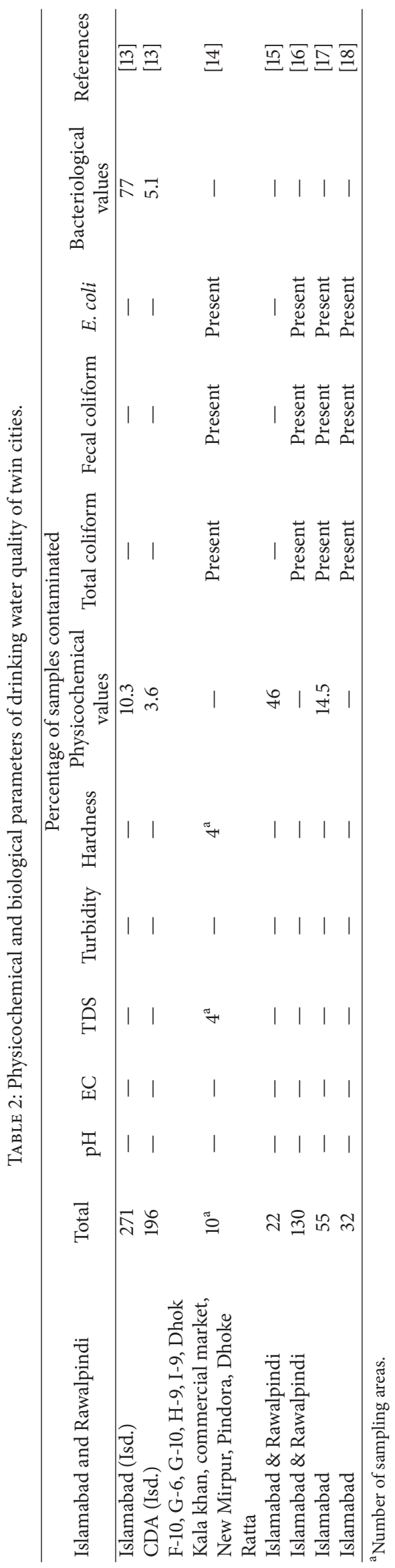




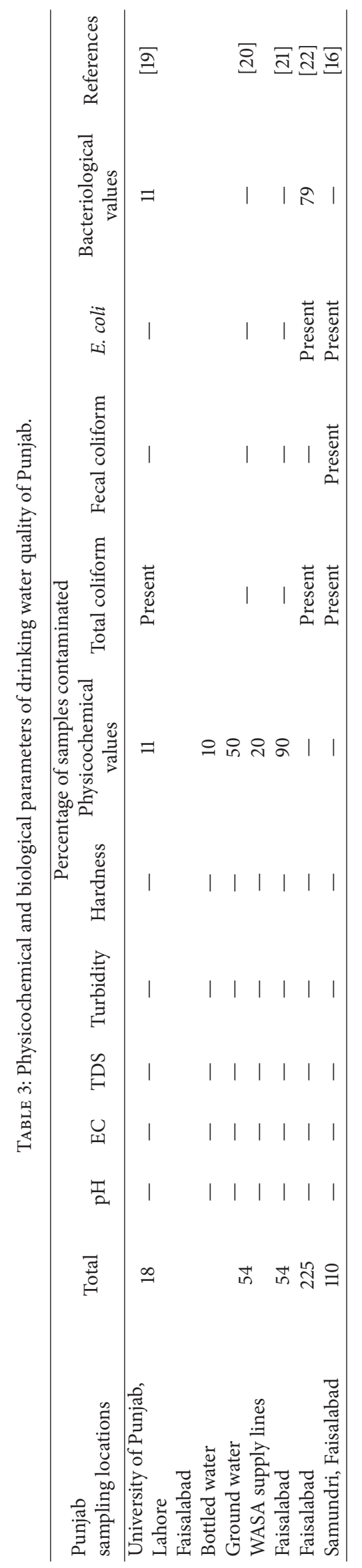


$\mathrm{pH}$ at seven sites was not within WHO limits while EC was within range. TDS, turbidity, carbonates, and bicarbonates were within recommended range of WHO but magnesium was higher than critical level [84]. In districts Bannu and Haripur, physicochemical and microbial analyses of various portable water samples indicated that the water quality was poor and below the quality parameters of WHO $[85,86]$.

The drinking water samples collected for bacteriological detection demonstrated that about ninety-two percent of water samples were detected as contaminated [87]. The underground water quality of Swabi was analyzed for drinking purpose. Physical and chemical parameters of tube wells such as temperature, $\mathrm{pH}, \mathrm{EC}$, TSS, and BOD were within range of WHO [88]. The analysis of heavy metal contamination in drinking water of urban as well as rural areas of Peshawar described that the drinking water was highly contaminated with $\mathrm{Pb}$ and $\mathrm{Cd}$. However, the concentrations of $\mathrm{As}, \mathrm{Cu}, \mathrm{Co}, \mathrm{Hg}, \mathrm{Ni}$, and $\mathrm{Zn}$ were significantly higher than WHO limits making water unfit for drinking purpose. Therefore, there is urgent need to take steps to improve treatment technologies [23].

The physical and chemical parameters of drinking water in Narangi and sounding areas of Swabi district demonstrated that the physical parameters were within permissible limits but regarding chemical parameters $\mathrm{Pb}$ and nitrite concentrations were found higher than WHO limits [89]. The water quality of Nomal valley, Gilgit-Baltistan, indicated that the $\mathrm{pH}$, temperature, turbidity, hardness, odor, taste, and alkalinity were within recommended range of WHO. But the microbial examination showed that all water samples were highly polluted [26].

Water samples collected for physicochemical analysis from tehsil of Jamrud and Landikotal, Khyber agency, showed that all parameters were within range set by WHO. However, the concentration of $\mathrm{Ca}$ and $\mathrm{Mg}$ exceeds the limits of WHO. The heavy metal concentrations were also below the WHO permissible limits. But $\mathrm{Cd}$ concentration was higher than WHO permissible limits [24].

Chemical and microbial aspects of water samples collected from four cities, that is, Abbottabad, Mardan, Peshawar, and Manghora, were analyzed. More than 55\% of all samples from these cities were highly contaminated with microbes. In KP, iron contamination was enlisted as second major contamination. In Peshawar and Mardan more than $38 \%$ and $67 \%$ of samples were contaminated with iron, respectively [2]. The samples of drinking water collected from various reservoirs (streams, tube wells, and water storage tanks) in Kohat (KP) showed that samples collected from tube wells in Shakarda, Ara Khail, and Lachi were found to be safe for drinking but storage tanks and wells were highly contaminated. The drinking water quality of Charsadda (KP) was also poor as in other regions and indicated that the concentration of sulphate, nitrate, and heavy metals was above the threshold level and they were contaminated with coliform bacteria [90].

The microbial and physical investigation of drinking water quality in new urban Peshawar indicated that the $\mathrm{pH}$ was within permissible limits but the value of EC in five tube wells, seven supply channels, and nine storage tank samples was found above critical values. Similarly, the TSS values of water samples collected from supply channels, storage points, and tube wells were $30 \%, 60 \%$ and $10 \%$ beyond the critical limits of WHO. Bacteriological analysis showed that about one-third of all samples were not detected to have bacteriological contamination, while others were contaminated [25].

The water quality from different villages of Nagar valley revealed that all the tested parameters, that is, temperature, $\mathrm{pH}$, turbidity, electrical conductivity, total dissolved solids, total coliform bacteria, total fecal bacteria, calcium hardness, cyanuric acid, and total alkalinity, were meeting the prescribed standards of WHO and EPA [91] as shown in Table 4.

7.4. Water Quality Status in Baluchistan. Biological and chemical water quality of Baluchistan are not satisfactory as revealed by various studies. In four cities of Baluchistan, that is, Ziarat, Loralai, Quetta, and Khuzdar, the water quality was badly contaminated with microorganisms making water unfit for human use. Water samples of these cities showed that $\mathrm{NO}_{3}$ concentration was higher than the recommended limits of WHO. About $50 \%$ of water samples, collected from Ziarat, were found highly contaminated with $\mathrm{NO}_{3}$ [2]. The drinking water quality assessment of different colonies in Quetta city revealed that $\mathrm{pH}$, TDS, and hardness value of all samples were within the WHO range but $50 \%$ of the samples were found to have high EC value and COD of all samples was above the critical limits of WHO [29]. The drinking water quality of Quetta was inadequate having bad taste, foul smell/odor, change in appearance, and pathogens being 57\%, 44\%, 39\%, and $60 \%$, respectively [28].

Temperature examination revealed a little fluctuation in results between 12.10 and $13.50^{\circ} \mathrm{C}$. The highest value was determined in Thole channel water while the lowest was found in Nilt tank water. According to WHO and EPA, turbidity must not exceed $5 \mathrm{NTU}$ and water having turbidity less than 1.00 NTU is excellent for domestic consumption. Turbidity of all samples was less than 5 NTU [91]. The surface and groundwater sources of drinking water throughout Baluchistan were highly contaminated with coliforms, heavy metals, and pesticides. Human activities like improper disposal of municipal and industrial effluents and indiscriminate applications of agrochemicals in agriculture are the main factors contributing to the deterioration of water quality [92]. The fluoride concentration in various drinking water samples collected from tap and wells water in Quetta indicated that all samples were within permissible limits of WHO except one sample of tap water [93].

The bacteriological and physicochemical study of Hingol River situated at Hingol National Park was carried out, where the majority of its inhabitants are leading nomadic life style $[94,95]$ and consume the water of the river as no alternative water resources are available. The physicochemical parameters of the samples collected were according to the NSDWQ standards. But the TDS value was greater than the permissible limits in postmonsoon. The BOD concentration was also relatively higher [27] as shown in Table 5.

7.5. Water Quality Status in Sindh. The drinking water quality of Khairpur, Sindh, showed high level coliform and fecal 


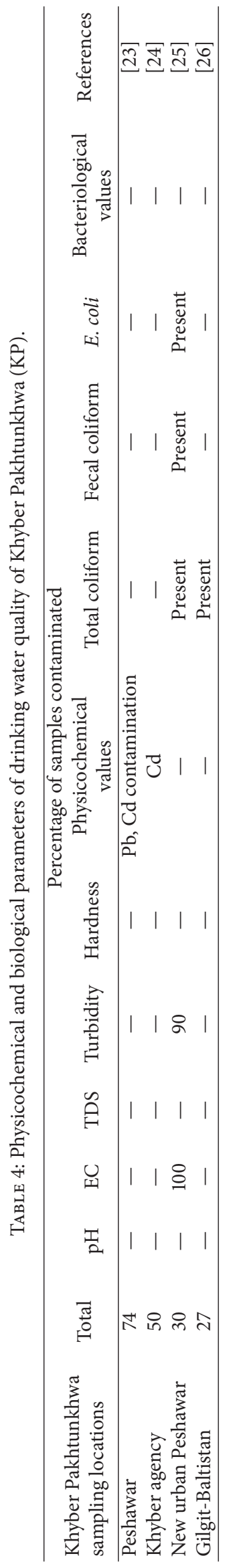




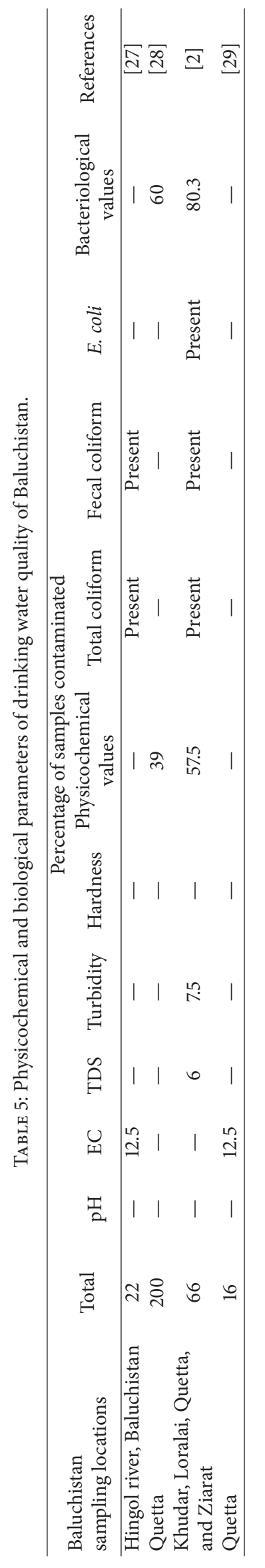


coliform contamination in drinking water at different points; therefore, it is not suitable for drinking purpose. It is evident from the results (high coliform and fecal coliform count at all 3 levels) that the quality of drinking water is further deteriorated in the distribution system which may be due to the leakage of pipes where sewage water enters into the municipal water. At the consumer level, the drinking water is getting more contaminated due to the unhygienic handling and uncovered storage tanks. Drinking water quality should have no coliform as well as fecal coliform present in $100 \mathrm{~mL}$ or 0 colony forming units (cfu) per $100 \mathrm{~mL}$ WHO [96].

The ground water of different villages in district Khairpur, Sindh, was analyzed physicochemically for drinking and irrigation purposes. The chemical and physical characteristics of all samples were above the WHO guidelines and water was not fit for drinking as well as for irrigation purposes [30]. Bacteriological and physicochemical examination of groundwater in the coastal areas of Sindh indicated that groundwater was unfit for drinking purpose. Phosphate and sulphate concentrations were within range. But, organic and fecal contamination was higher than turbidity and salinity [33]. The ground water quality of various districts in Sindh showed that the $\mathrm{pH}$ of water samples was within limits of WHO, while turbidity and most of the chemical parameters were above the critical limits [32].

Water shortage is a major issue in Karachi city, which is worse in slum areas having poor infrastructure and limited facilities. The physicochemical analysis of drinking water supply lines in Orangi Town, Karachi, showed that physicochemical characteristics were within WHO permissible limits except sulphates. The microbial investigation revealed that all samples were highly contaminated with total coliform, fecal coliform, and E. coli. The presence of microbial contamination indicated poor water supply and sewage infrastructure [31]. Microbial and physicochemical parameters of water supplied by WASA in Gulshan-e-Iqbal demonstrated that the $\mathrm{pH}$, temperature, turbidity, conductivity, TDS, and As were satisfactory to the guidelines of WHO but only three samples were contaminated with microbes because of leakage water mains and cross-connections between drinking water supply lines and sewage [34] as shown in Table 6.

Qualitative analysis of water resources that are used for drinking purposes showed that the physical parameters of three sampling sites such as bore well, dug well, and hand pumps were not according to the recommendations of PEPA and WHO [97]. But, however, samples collected from tube well were according to the PEPA and WHO [97] recommendations. Turbidity was found in the samples collected from hand pumps, bore well, and dug well but tube well water samples were found to be turbidity-free. The EC and contents of TS, TDS, and TSS were above the WHO [97] recommendations in the samples collected from hand pumps, bore well, and dug well. All these parameters of samples collected from tube well water were within WHO limits [65].

Drinking water quality of the Sindh province is also poor as that of other provinces. About $67 \%-93 \%$ of samples collected from different locations in three main cities, that is, Sukkur, Hyderabad, and Karachi, showed that water is unsafe for drinking purposes due to microbial and chemical contamination [2]. Guidelines for drinking water WHO [98] and National Standards for Drinking Water for Pakistan NSDWQ [99] recommend that E. coli or thermotolerant coliform bacteria must not be detectable in all water directly intended for drinking. However, total and fecal coliform bacteria were detected in samples collected from drinking water supply of Badin city and the water samples were found to be unfit for drinking [100].

The $\mathrm{pH}$ value of Keenjhar lake, located in Theta, Sindh, was within limits but color was brown to dark brown which is not acceptable for drinking purposes. The EC values of the samples were found to be above the WHO permissible limits.

\section{Human Health Impacts}

Due to the poor sanitation system, treatment, and monitoring, drinking water quality deteriorates. The presence of toxic chemicals and bacteria in drinking water causes adverse effect on human health. Due to the fecal contamination, people have been suffering from waterborne diseases. In rural and urban areas of Pakistan, cases of waterborne diseases, typhoid, dysentery, cholera, and hepatitis are systematically reported. However, it is very difficult to properly quantify the danger due to several reasons. They include underreporting of diseases and poor record maintenance in healthcare centers and hospitals related to diseases caused by poor water quality [101].

Several studies have reported health-related problems due to poor drinking water quality. For example, the concentration of nitrate $\left(\mathrm{NO}_{3}\right)$ was found above the permissible limits causing blue baby syndrome in bottle fed babies [44]. The average daily intake of potassium $(\mathrm{K})$ by adults was noted to be less than $0.1 \%$ through water [102]. Significant quantity of $\mathrm{K}$ is very important, the same as other elements for proper functioning of body. Diseases such as hypertension, kidney diseases, heart problem, muscle weakness, bladder weakness, and asthma may be caused due to K level decreasing in blood and increase in level may cause cysts, reduced renal function, rapid heartbeat, and improper metabolism of proteins [103]. The major source of sodium $(\mathrm{Na})$ is the deposition of minerals into the water. Decrease in $\mathrm{Na}$ level in body causes low blood pressure, fatigue, mental apathy, and depression and increase in level may cause brain stroke, kidney problem, nausea, headaches, hypertension, and stomach problem [104]. Cardiovascular disease may be caused by the basic cations deficiency such as calcium (Ca) and magnesium $(\mathrm{Mg})$ [105]. The basic and important element for myoglobin and hemoglobin and for numerous other enzymes is iron (Fe). The higher level of $\mathrm{Fe}$ in body also causes many health problems such as weakening of cardiovascular tissue, central nervous system, kidney, and liver, blood problems, vomiting, and diarrhea [106].

In Peshawar, most of water samples were found to be contaminated with coliform bacteria. In Rawalpindi, the gastroenteritis was reported in 2000; the contaminated water was the source. In Karachi, it was also found that the drinking water samples were heavily contaminated with total and fecal coliform. In Khairpur, a city of 0.12 -million population, 


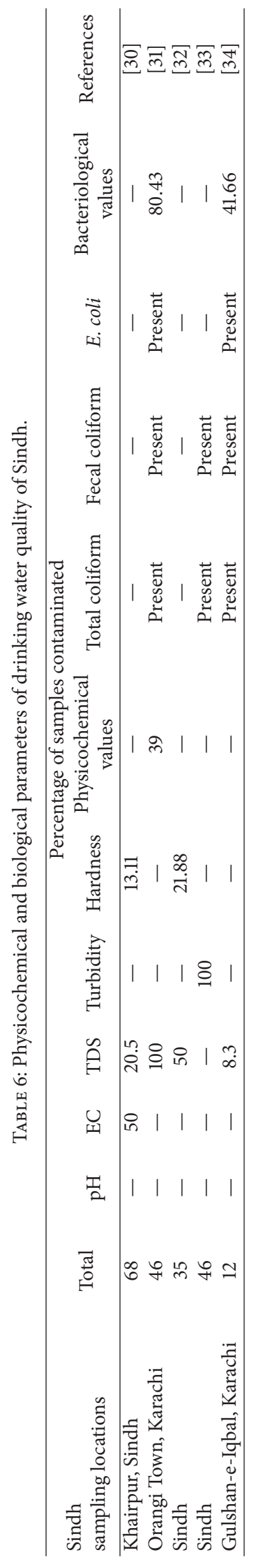


water quality seems to be poor and therefore could be a potential source for waterborne diseases especially among children.

In Islamabad and Rawalpindi, 4000 cases of hepatitis were registered and were due to unfit drinking water and improper treatment [107]. Dental fluorosis was also found in many districts such as Raiwind, Pattoki, and Kasur [43]. Effluents coming from tanneries contaminate the ground water in Kasur and cause skin and abdominal problems [108].

Unsafe drinking water is a major cause of the disease, which otherwise may be prevented, in particular in young children in developing countries. Pathogens present in drinking water including many viral, bacterial, and protozoan agents caused 2.5 million deaths from endemic diarrheal disease each year [9]. Major health problems were reported as gastroenteritis $(40 \%-50 \%)$, diarrhea $(47 \%-59 \%)$, dysentery (28-35\%), hepatitis A (32\%-38\%), hepatitis B (16\%-19\%), and hepatitis $\mathrm{C}(6-7 \%)$ by respondents [29]. In southern Sind, waterborne diseases such as diarrhea, vomiting, gastroenteritis, dysentery, and kidney problem are caused by polluted drinking water [109].

\section{Management Strategies}

Management strategies should cover protection of sources from contamination, drinking water distribution lines upgradation and their proper maintenance, and monitoring and awareness of the people [110].

9.1. Legislative Control. There is a poor framework for the legislation of drinking water supplies. Drinking water quality standards should be provisionally established for the treatment and maintenance of drinking water distribution system. Water and Sanitation Agency (WASA) should take action with the help of private institutions to protect water resources and control pollution from its source. A great attention is also required to stop the saline water intrusion into the fresh ground water resources.

9.2. Governance. Government should take action for the maintenance, proper functioning, and handling of already present drinking water treatment plants. There is a lack of proper sampling system of the drinking water treatment plants to ensure that water is safe and fit for drinking in urban areas of Pakistan. To stop the spread of waterborne diseases, there is need for proper functioning, inspection, and sampling analysis twice a year to ensure safe drinking water according to the quality standards.

Proper maintenance of water distribution system and chlorination should be done according to the law and regulations to kill pathogens. Government should provide the latest and reliable instruments and trained personals for the drinking water quality analysis.

In Pakistan, there are few industries that have their own water treatment plant to treat wastewater. Government should take strict action for their industrial effluent disposal according to the NEQS under the 1997 Act. If any industry is found to be violating the rules, it should be punished with heavy fine and imprisonment.
9.3. General. Public awareness campaigns should be started at school, college, university, and community level to address the significance of secure drinking water. NGOs might act in this facet. Rural communities should adopt safe control methods for protecting water storage in houses and simple disinfection technologies of drinking water.

A lot of studies show that boiled drinking water reduces risk of waterborne diseases $[111,112]$. A study was conducted by [113] in three districts of Punjab's urban as well as rural areas, that is, Toba-Tek Singh, Multan, and Rawalpindi. All the samples were collected through multistage sampling technique. The outcomes indicated that $45.1 \%$ of population of these three districts were not using National Quality Standards to improve water quality and these people were suffering from diarrhea. The remaining population of these three districts use National Quality Standards and were not found ill. Social and economic conditions of the families also play a vital role in reduction of diarrheal disease. It is also seen that mother's education, household income, and living style are correlated to the quality of drinking water and also improve health status of the family.

\section{Conclusion}

This review documented the studies conducted in Pakistan on drinking water quality status and contamination, which accounted sewerage water (fecal) mixing with drinking water as dominant and primary contaminant due to the poor sanitation and sewerage system. Second source of contamination is chemical pollution from toxic substances from the industrial effluents, textile dyes, pesticides, nitrogenous fertilizers, arsenic, and other chemicals. There is a need to maintain and upgrade regular inspection of already present treatment plants. Nowadays, Government of Pakistan is going to install drinking water filter all over Pakistan. The results drew attention that sewerage contamination with drinking water must be considered as an important environmental and health issue.

\section{Conflicts of Interest}

All authors declare having no conflicts of interest regarding the publishing of this paper.

\section{Acknowledgments}

This study was funded by the National Natural Science Fund (Project no. 31501342) of China (2013AA102601).

\section{References}

[1] "Water quality testing protocol," Water Aid in Pakistan, 2012.

[2] Z. A. Soomro, M. I. A. Khokhar, W. Hussain, and M. Hussain, "Drinking water Quality challenges in Pakistan," World Water Day, pp. 17-28, 2011.

[3] S. L. Postel, G. C. Daily, and P. R. Ehrlich, "Human appropriation of renewable fresh water," Science, vol. 271, no. 5250, pp. 785-788, 1996.

[4] K. Park, Preventive and Social Medicine, M/S BanarsidusBhanot, Prem Nagar, Jabalpur, India, 25th edition, 2007. 
[5] L. M. Prescott, J. P. Harley, and D. A. Klein, Microbiology, McGraw Hill, 5th edition, 2002.

[6] D. R. Arora, Textbook of Microbiology, CBS Publishor \& Distributor, New Delhi, India, 2nd edition, 2007.

[7] M. J. Pelczar, E. C. S. Chan, and N. R. Krieg, Microbiology, Tata McGraw Hill, New Delhi, India, 5th edition, 2007.

[8] A. A. Patoli, B. B. Patoli, and V. Mehraig, "High prevalence of Multi-drug resistant Escherichia Coli in drinking water samples from Hyderabad," Gomal Journal of Medical Sciences, vol. 8, pp. 23-26, 2010.

[9] M. Kosek, C. Bern, and R. L. Guerrant, "The global burden of diarrhoeal disease, as estimated from studies published between 1992 and 2000," Bulletin of the World Health Organization, vol. 81, no. 3, pp. 197-204, 2003.

[10] S. K. Agarwal, Pollution Management, Water Pollution, A.P.H. Publishing Corporation, New Delhi, India, 2002.

[11] R. Chhatwal, Dictionary of Environmental Chemistry, Publication, New Delhi, India, 1990.

[12] F. K. Bangash and S. U. Khan, "Aesthetic Quality Evaluation of Drinking Water of Peshawar Valley," 2001.

[13] O. H. Sun, S. H. Chung, J. A. Nasir, and N. U. Saba, Drinking Water Quality Monitoring in Islamabad, Islamabad: National Institute of Health \& Korea International Cooperation Agency, 2001.

[14] S. Mehmood, A. Ahmad, N. Khalid, and T. Javed, "Drinking water quality in capital city of Pakistan," vol. 2, 2013.

[15] R. Shabbir and S. S. Ahmad, "Use of geographic information system and water quality index to assess groundwater quality in rawalpindi and islamabad," Arabian Journal for Science and Engineering, vol. 40, no. 7, pp. 2033-2047, 2015.

[16] M. Shoaib, M. J. Asad, S. Aziz et al., "Prevalence of pathogenic microorganisms in drinking water of Rawalpindi and Islamabad," World Journal of Fish and Marine Sciences, vol. 8, pp. 1420, 2016.

[17] T. Ahmed, S. Imdad, and N. M. Butt, "Bacteriological assessment of drinking water of Islamabad Capital Territory, Pakistan," Desalination and Water Treatment, vol. 56, no. 9, pp. 2316-2322, 2015.

[18] A. Hisam, M. U. Rahman, E. Kadir, N. A. Tariq, and S. Masood, "Microbiological contamination in water filtration plants in Islamabad," Journal of the College of Physiciansand Surgeons Pakistan, vol. 24, pp. 345-350, 2014.

[19] N. Shahid, Z. Zia, M. Shahid et al., "Assessing drinking water quality in Punjab, Pakistan," Polish Journal of Environmental Studies, vol. 24, no. 6, pp. 2597-2606, 2015.

[20] M. Yamin, A. Nasir, M. Sultan, W. WanIsmail, R. Shamshiri, and A. N. Akbar, "Impact of sewage and industrial effluents on water quality in Faisalabad, Pakistan," Advances in Environmental Biology, vol. 9, pp. 53-58, 2015.

[21] A. Nasir, M. S. Nasir, I. Shauket, S. Anwar, and I. Ayub, "Impact of samanduri drain on water resources of Faisalabad," Advances in Environmental Biology, vol. 10, pp. 155-160, 2016.

[22] H. Zulfiqar, Q. Abbas, A. Raza, and A. Ali, "Determinants of safe drinking water in pakistan: a case study of faisalabad," Journal of Global Innovations in Agricultural and Social Sciences, vol. 04, no. 01, pp. 40-45, 2016.

[23] S. Khan, R. Rauf, S. Muhammad, M. Qasim, and I. Din, "Arsenic and heavy metals health risk assessment through drinking water consumption in the Peshawar District, Pakistan," Human and Ecological Risk Assessment, vol. 22, no. 3, pp. 581-596, 2016.
[24] S. Yousaf, S. Begum, I. Afridi, M. Shakil, and M. Tariq, "Assessment of drinking water quality and human health risks in the tehsils of Jamrud and Landikotal, Khyber Agency, Pakistan," Journal of Himalayan Earth Sciences, vol. 49, no. 1, pp. 58-67, 2016.

[25] R. Amin, S. Ali, Z. Anwar, and J. Khattak, "Microbial analysis of drinking water and water distribution system in new urban Peshawar," Current Research Journal of Biological Sciences, vol. 4, pp. 31-737, 2012.

[26] H. Ali and M. S. Akhtar, "Peoples perception about poor quality of drinking water and its impact on human health in rural areas of tehsil Samundri Pakistan," International Journal of Science and Research, vol. 4, pp. 523-528, 2015.

[27] M. A. Khan, M. Lang, S. S. Shaukat, A. Alamgir, and T. Baloch, "Water quality assessment of hingol river, Balochistan, Pakistan," Middle-East Journal of Scientific Research, vol. 19, no. 2, pp. 306-313, 2014.

[28] M. Butt and S. M. Khair, "Cost of illness of water-borne diseases: a case study of Quetta," Journal of Applied and Emerging Sciences, vol. 5, 2014.

[29] S. S. Khan, H. Tareen, U. Jabeen et al., "Quality assessment of drinking water from the different colonies of Quetta city, Pakistan according to WHO Standards," Biological Forum: An International Journal, vol. 7, pp. 699-702, 2015.

[30] A. R. Shar, G. Q. Shar, N. U. H. Shar, W. B. Jatoi, L. A. Shar, and W. M. Ghouri, "Assessment of the quality of drinking water of Thari Mirwah Town and Surrounding villages," Pakistan Journal of Analytical and Environmental Chemistry, vol. 5, 2014.

[31] A. Alamgir, M. A. Khan, O. E. Hany et al., "Public health quality of drinking water supply in Orangi town, Karachi, Pakistan," Bulletin of Environment, Pharmacology and Life Sciences, vol. 4, pp. 88-94, 2015.

[32] W. M. Daudpota, N. U. N. Memon, and T. F. Miano, "Determination of ground water quality for agriculture and drinking purpose in Sindh, Pakistan," Science International, vol. 28, pp. 701-704, 2016.

[33] A. Alamgir, M. A. L. Khan, J. Schilling, S. S. Shaukat, and S. Shahab, "Assessment of groundwater quality in the coastal area of Sindh province, Pakistan," Environmental Monitoring and Assessment, vol. 188, no. 2, p. 78, 2016.

[34] S. A. Hussain, A. Hussain, U. Fatima, W. Ali, A. Hussain, and N. Hussain, "Evaluation of drinking water quality in urban areas of Pakistan, a case study of Gulshan-e-Iqbal Karachi, Pakistan," Journal of Biological and Environmental Science, vol. 8, pp. 6476, 2016.

[35] L. Lienyao, L. Chungsying, and K. Shyang-Lai, "Spatial diversity of chlorine residual in a drinking water distribution system," Journal of Environmental Engineering, vol. 130, pp. 1263-1268, 2004.

[36] C. L. Moe, M. D. Sobsey, G. P. Samsa, and V. Mesolo, "Bacterial indicators of risk of diarrhoeal disease from drinking-water in the Philippines," Bulletin of the World Health Organization, vol. 69, no. 3, pp. 305-317, 1991.

[37] J. Van Derslice and J. Briscoe, "Environmental interventions in developing countries: interactions and their implications," American Journal of Epidemiology, vol. 141, no. 2, pp. 135-144, 1995.

[38] S. A. Esrey, "Water, waste, and well-being: A multicountry study," American Journal of Epidemiology, vol. 143, no. 6, pp. 608-623, 1996. 
[39] S. Cairncross and P. Kolsky, "Water, waste and wellbeing: a multi country study (letter)," American Journal of Epidemiology, vol. 146, pp. 359-360, 1997.

[40] R. Bashir, H. Nawaz, and M. Khurshid, "Chemical analysis of underground water of Faisalabad city," Pakistan Journal of Biological Sciences, vol. 2, no. 3, pp. 715-719, 1999.

[41] “Chapter 2," in Pakistan National Conservation Strategy, p. 36, 1992.

[42] P. J. Chilton et al., "Pakistan water quality mapping and management project," Pakistan Integrated Household Survey (PIHS) Islamabad, Federal Bureau of Statistics, Government of Pakistan, 2000.

[43] J. A. Aziz, "National water quality strategy," Report Submitted to The Asian Development Bank as Part of Water Resources Strategy Study, ADB, TA 3130 PAK, Islamabad, Ministry of Water and Power, 2002.

[44] F. X. R. Van Leeuwen, "Safe drinking water: The toxicologist's approach," Food and Chemical Toxicology, vol. 38, no. 1, pp. S51S58, 2000.

[45] G. Holgate, "Water Quality: DETR consultation on new regulations for drinking water," Environment and Waste Management, vol. 3, pp. 105-112, 2000.

[46] G. H. Huang and J. Xia, "Barriers to sustainable water-quality management," Journal of Environmental Management, vol. 61, no. 1, pp. 1-23, 2001.

[47] “C. R. P., Country Report, Pakistan, Global Water Partnership, Draft South Asia - Water Vision," vol. 2025, 2000.

[48] M. A. Kahlown, M. A. Tahir, H. Rasheed, and K. P. Bhatti, "Water quality status, national water quality monitoring programme," Fourth Technical Report PCRWR 5, 2006.

[49] R. Nils, "Drinking water crisis in Pakistan and issue of bottled water," Actioned Pakistan, 2005.

[50] World Health Organization, "WHO(1972-73) Technical Report," Tech. Rep. Series No. 505, 532, Geneva, Switzerland.

[51] M. A. Tahir, M. A. Bhatti, and A. Majeed, Survey of Drinking Water Quality in the Rural Areas of Rawalpindi District, Pakistan Council for Research in Water Resources, Islamabad, pp. 35-39, 1994.

[52] S. Husain, "Water availability shrinking fast in Pakistan," study thenews.com.pk." The News International, Pakistan. shrinkingfast-in-Pakistan-study," 2012.

[53] K. Mustafa, "Pakistan's per Capita Water Availability Dwindling," 2012.

[54] P. J. Chilton, "Pakistan water quality mapping and management project," Scoping Study-Draft Final Report WELL Task 568, Water, Engineering and Development Centre, Loughborough University and London School of Hygiene and Tropical Medicine, Loughborough, UK, 2001.

[55] M. A. Tahir, B. A. Chandio, M. Abdullah, and A. Rashid, "Drinking water quality monitoring in the rural areas of Rawalpindi," in Proceedings of the National Workshop on Quality of Drinking Water, pp. 35-39, Pakistan Council for Research in Water Resources, Islamabad, Pakistan, 1998.

[56] WHO, Guidelines for Drinking Water Quality, vol. 2, World Health Organization, Geneva, Switzerland, 1996.

[57] S. Shuja and M. Jaffar, "Drinking water quality guideline values, chemical and physical aspects," in Proceedings of the National Workshop on Quality of Drinking Water, vol. 8, pp. 25-28, Pakistan Council of Research in Water Resources \& Chemical Society of Pakistan, Islamabad, Pakistan, 1998.
[58] M. A. Awan, M. T. Siddiqui, R. A. Khan, and A. H. Shah, "Combined effect of salinity and industrial effluents on the growth of Eucalyptus camaldulensis dehnh," Pakistan Journal of Agricultural Sciences, 2002.

[59] T. A. Howell, "Enhancing water use efficiency in irrigated agriculture," Agronomy Journal, vol. 93, no. 2, pp. 281-289, 2001.

[60] K. M. A. Karim, M. A. Khattak, and R. A. Shah, "Pollution studies of Kabul River and Kheshki Lake," International Journal of Engineering and Applied Sciences, vol. 2, pp. 20-24, 1985.

[61] M. Aslam and M. Ahmed, "An inquiry into the incidence and prevalence of water borne diseases: a case history of Faisalabad," Journal of Animaland Plant Sciences, vol. 3, p. 101, 1993.

[62] S. B. Jonnalagadda and G. Mhere, "Water quality of the odzi river in the Eastern Highlands of Zimbabwe," Water Research, vol. 35, no. 10, pp. 2371-2376, 2001.

[63] US Environmental Protection Agency (US EPA) Toxicology of Metals, Environmental Health Effects Research Series, vol. II, Washington, DC, EPA/ 600/1-77-022, 1977.

[64] Pakistan Environmental Protection Agency, Ministry of Environment, National Standards for Drinking Water Quality (NSDWQ), 2008.

[65] S. Yousaf, A. Zada, and M. Owais, "Physico-chemical characteristics of potable water of different sources in district Nowshera: a case study after flood - 2010," Journal of Himalayan Earth Sciences, vol. 46, no. 1, pp. 83-87, 2013.

[66] A. A. Saddozai, S. Khalil, and T. Hameed, "Microbial quality of food snacks and drinking water in Islamabad schools and colleges," Pakistan Journal of Agriculture Research, vol. 2, pp. 3-4, 2009.

[67] S. Farooq, I. Hashmi, I. A. Qazi, S. Qaiser, and S. Rasheed, "Monitoring of Coliforms and chlorine residual in water distribution network of Rawalpindi, Pakistan," Environmental Monitoring and Assessment, vol. 140, no. 1-3, pp. 339-347, 2008.

[68] I. Hashmi, S. Farooq, and S. Qaiser, "Incidence of fecal contamination within a public drinking water supply in Ratta Amral, Rawalpindi," Desalination and Water Treatment, vol. 11, no. 1-3, pp. 124-131, 2009.

[69] A. Mashiatullah, M. Z. Chaudhary, M. S. Khan, T. Javed, and R. M. Qureshi, "Coliform bacterial pollution in Rawal Lake, Islamabad and its feeding streams/river," Nucleus, vol. 47, pp. 35-40, 2010.

[70] W. A. Jadoon, M. Arshad, and I. Ullah, "Spatio-temporal microbial water quality assessment of selected natural streams of Islamabad, Pakistan," Records Zoological Survey of Pakistan, vol. 21, pp. 14-18, 2012.

[71] H. Azhar, Determination of Drinking Water Quality from Source to Consumer in Islamabad, Islamabad: Health Services Academy, Faculty of Medicine, Quaid-e-Azam University, Islamabad, Pakistan, 1996.

[72] K. M. Ihsanullah, T. N. Khattak, and A. Sattar, "Determination of different contaminants in selective drinking water samples," Nucleus, vol. 3, pp. 691-697, 1999.

[73] P. K. Jensen, J. H. J. Ensink, G. Jayasinghe, W. van der Hoek, S. Cairncross, and A. Dalsgaard, "Effect of chlorination of drinking-water on water quality and childhood diarrhoea in a village in Pakistan," Journal of Health Population and Nutrition, vol. 21, no. 1, pp. 26-31, 2003.

[74] M. A. Zia, K. U. Rehman, F. Anjum, and R. Latif, "Microbial and chemical aspects of drinking water and treatment enhanced its quality," Journal of Research (Sciences), vol. 16, pp. 11-18, 2005. 
[75] P. W. Ramteke, J. W. Bhattacharjee, S. P. Pathak, and N. Kalra, "Evaluation of coliforms as indicators of water quality in India," Journal of Applied Bacteriology, vol. 72, no. 4, pp. 352-356, 1992.

[76] K. Hu, Y. Huang, H. Li, B. Li, D. Chen, and R. E. White, "Spatial variability of shallow groundwater level, electrical conductivity and nitrate concentration, and risk assessment of nitrate contamination in North China Plain," Environment International, vol. 31, no. 6, pp. 896-903, 2005.

[77] I. Hashmi, S. Farooq, and S. Qaiser, "Chlorination and water quality monitoring within a public drinking water supply in Rawalpindi Cantt (Westridge and Tench) area, Pakistan," Environmental Monitoring and Assessment, vol. 158, no. 1-4, pp. 393-403, 2009.

[78] S. Haydar, M. Arshad, and J. Aziz, "Evaluation of drinking water quality in urban areas of Pakistan, A case study of southern Lahore," Pakistan Journal of Engineering and Applied Sciences, vol. 5, pp. 16-23, 2009.

[79] A. Q. K. Sulehria, Y. S. Mustafa, N. Siddique, and S. Afzal, "Determination of drinking water quality from source to consumer in sabzazar, Lahore," Science International, vol. 24, pp. 101-104, 2012.

[80] M. B. Shakoor, N. K. Niazi, I. Bibi et al., "Unraveling health risk and speciation of arsenic from groundwater in rural areas of Punjab, Pakistan," International Journal of Environmental Research and Public Health, vol. 12, no. 10, pp. 12371-12390, 2015.

[81] A. Yasar, N. Y. Khan, A. Batool, A. B. Tabinda, R. Mehmood, and A. lqbal, "Women perception of water quality and its impacts on health in Gangapur, Pakistan," Pakistan Journal of Nutrition, vol. 10, no. 7, pp. 702-706, 2011.

[82] S. Farid, M. K. Baloch, and S. A. Ahmad, "Water pollution: major issue in urban areas," International Journal of Water Resources and Environmental Engineering, vol. 4, pp. 55-65, 2012.

[83] T. A. Zahoorullah, "Quality of drinking water in rural Peshawar," Pakistan Journal of Medical Research, vol. 42, pp. 85-89, 2003.

[84] A. R. Khan, M. Khan, G. A. Marwat, and M. Riaz, "Potable water quality characteristics of the urban areas of Peshawar (Pakistan)," Journal of the Chemical Society of Pakistan, vol. 27, pp. 239-245, 2005.

[85] M. Khan, M. A. Khwaja, and M. Riaz, "Physico-chemical characteristics of subsurface water of Haripur area Hazara," Journal of the Chemical Society of Pakistan, vol. 21, pp. 347-352, 1999.

[86] A. R. Khan, M. Khan, and M. Riaz, "Quality characteristics of potable water from different sources of district Bannu and there possible health impacts," Journal of the Chemical Society of Pakistan, vol. 21, pp. 106-113, 1999.

[87] A. Hamida, A. Javed, N. A. Mohammad, and I. Musaddiq, "Bacteriological analysis of drinking water of hand pumps in different schools of District Peshawar (Pakistan)," Journal of Food Science, vol. 16, pp. 34-38, 2006.

[88] R. N. Nasrullah, B. Hamida, and I. Mudassar, "Pollution load in industrial effluent and ground water of Gadoon Amazai Estate Industrial (GAEI) Swabi, NWFP," Research Journal of Agriculture and Biological Sciences, vol. 1, pp. 18-24, 2006.

[89] M. Tariq, S. Khan, L. Ali et al., "Assessment of drinking water quality in Narangi and surrounding areas of district Swabi, Pakistan," Journal of Himalayan Earth Sciences, vol. 48, no. 1, pp. 81-88, 2015.

[90] S. Khan, M. Shahnaz, N. Jehan, S. Rehman, M. T. Shah, and I. Din, "Drinking water quality and human health risk in
Charsadda district, Pakistan," Journal of Cleaner Production, vol. 60, pp. 93-101, 2013.

[91] S. Ali, A. Hussain, A. Ali, and M. S. Awan, "Drinking water quality assessment in some selected villages of Nagar Valley Gilgit Baltistan, Pakistan," Journal of Chemical Biological and Physical Sciences, vol. 3, pp. 567-574, 2012.

[92] S. Kanwa, M. K. Taj, S. Saddozai et al., "Water pollution in Baluchistan province of Pakistan," International Journal of Engineering and Applied Sciences, vol. 2, pp. 89-90, 2015.

[93] U. Jabeen, S. Fahmid, T. Zameer, and S. Qureshi, "Determination of fluoride concentration in drinking water and its comparison with mineral water samples in Quetta, Pakistan," Academia Journal of Scientific Research, vol. 4, pp. 081-084, 2016.

[94] A. Mian, "On biology of houbara bustard (Chlamydotis undulata macqueenii) in Balochistan, Pakistan: phytosociological analysis of habitat," Pakistan Journal of Biological Sciences, vol. 6, no. 14, pp. 1282-1295, 2003.

[95] S. Ali Ghalib, A. Jabbar, J. Wind, A. Zehra, and D. Abbas, "Avifauna of hingol national park, Balochistan," Pakistan Journal of Zoology, vol. 40, no. 5, pp. 317-330, 2008.

[96] A. H. Shar, Y. F. Kazi, N. A. Kanhar, I. H. Soomro, S. M. Zia, and P. B. Ghumro, "Drinking water quality in Rohri city, Sindh, Pakistan," African Journal of Biotechnology, vol. 9, no. 42, pp. 7102-7107, 2010.

[97] "World Health Organization Guideline for Drinking Water Quality," Geneva, Switzerland, pp. 2231-2236, 1999.

[98] WHO Annual Report, World Health Organization, 2011.

[99] "National Standards for Drinking Water Quality, Pakistan Environment Protection Agency, Ministry of Environment, Government of Pakistan, 2008.

[100] A. Ahmed, T. M. Noonari, H. Magsi, and A. Mahar, "Risk assessment of total and faecal coliform bacteria from drinking water supply of Badin city, Pakistan," Journal of Environmental Professionals Sri Lanka, vol. 2, no. 1, pp. 52-64, 2013.

[101] "Health Management Information System," Department of Health, Lahore, Punjab, Pakistan, 1997.

[102] R. E. Latorre, L. Toro, J. R. Sotelo, and J. C. Benech, "Balls, chains and potassium channels, calcium and cellular metabolism," in Transport and Regulation, pp. 59-71, Plenum Press, New York, NY, USA, 1997.

[103] J. Marijic and L. Toro, "Voltage and calcium-activated K channels of coronary smooth muscle," in Heart Physiology and Pathophysiology, N. Sperelakis, Y. Kurachi, A. Terzic, and M. Cohen, Eds., pp. 309-325, Academic Press, Cambridge, Mass, USA, 2000.

[104] G. Robert and G. Mari, Issue Paper on Human Health Effects of Metals, US Environmental Protection Agency Risk Assessment Forum, Washington, DC, USA, 2003.

[105] C.-Y. Yang, C.-C. Chang, S.-S. Tsai, and H.-F. Chiu, "Calcium and magnesium in drinking water and risk of death from acute myocardial infarction in Taiwan," Environmental Research, vol. 101, no. 3, pp. 407-411, 2006.

[106] S. B. Goldhaber, "Trace element risk assessment: essentiality vs. toxicity," Regulatory Toxicology and Pharmacology, vol. 38, no. 2, pp. 232-242, 2003.

[107] A. S. Dil, "100 communicable diseases associated with water," in Environmental Pollution, J. Hanif and M. I. Hanif, Eds., Scientific Information Division, Pakistan Institute of Nuclear Science and Technology, Islamabad, Pakistan, 1997.

[108] United Nation Industrial Development Organization (UNIDO), Annual Report, 1999. 
[109] M. Memon, M. S. Soomro, M. S. Akhtar, and K. S. Memon, "Drinking water quality assessment in Southern Sindh (Pakistan)," Environmental Monitoring and Assessment, vol. 177, no. 1-4, pp. 39-50, 2011.

[110] United States Environmental Protection Agency Understanding the Safe Drinking-Water Act, Washington DC, 1999.

[111] E. Rice and C. Johnson, "Cholera in Peru," The Lancet, vol. 338, no. 8764 , p. $455,1991$.

[112] P. A. Blake, S. Ramos, K. L. MacDonald et al., "Pathogen-specific risk factors and protective factors for acute diarrheal disease in urban Brazilian Infants," Journal of Infectious Diseases, vol. 167, no. 3, pp. 627-632, 1993.

[113] S. Kausar, K. Asghar, S. M. Anwar, F. Shaukat, and R. Kausar, "Factors affecting drinking water quality and human health at household level in Punjab, Pakistan," Statistics, vol. 100, no. 100, 2011. 

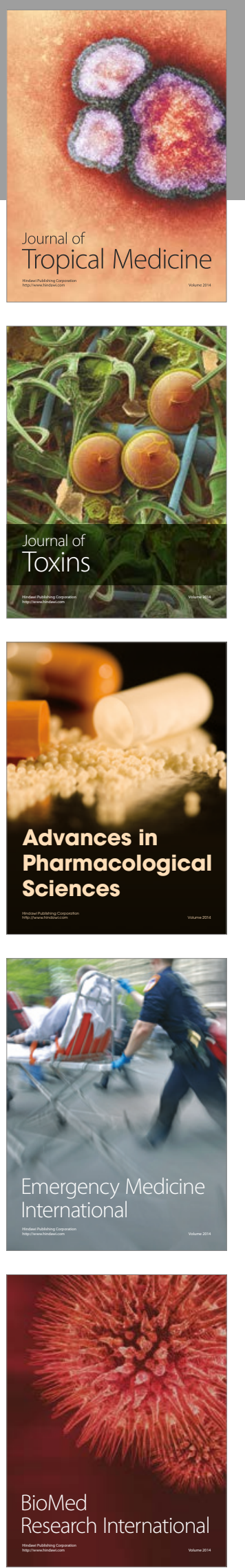
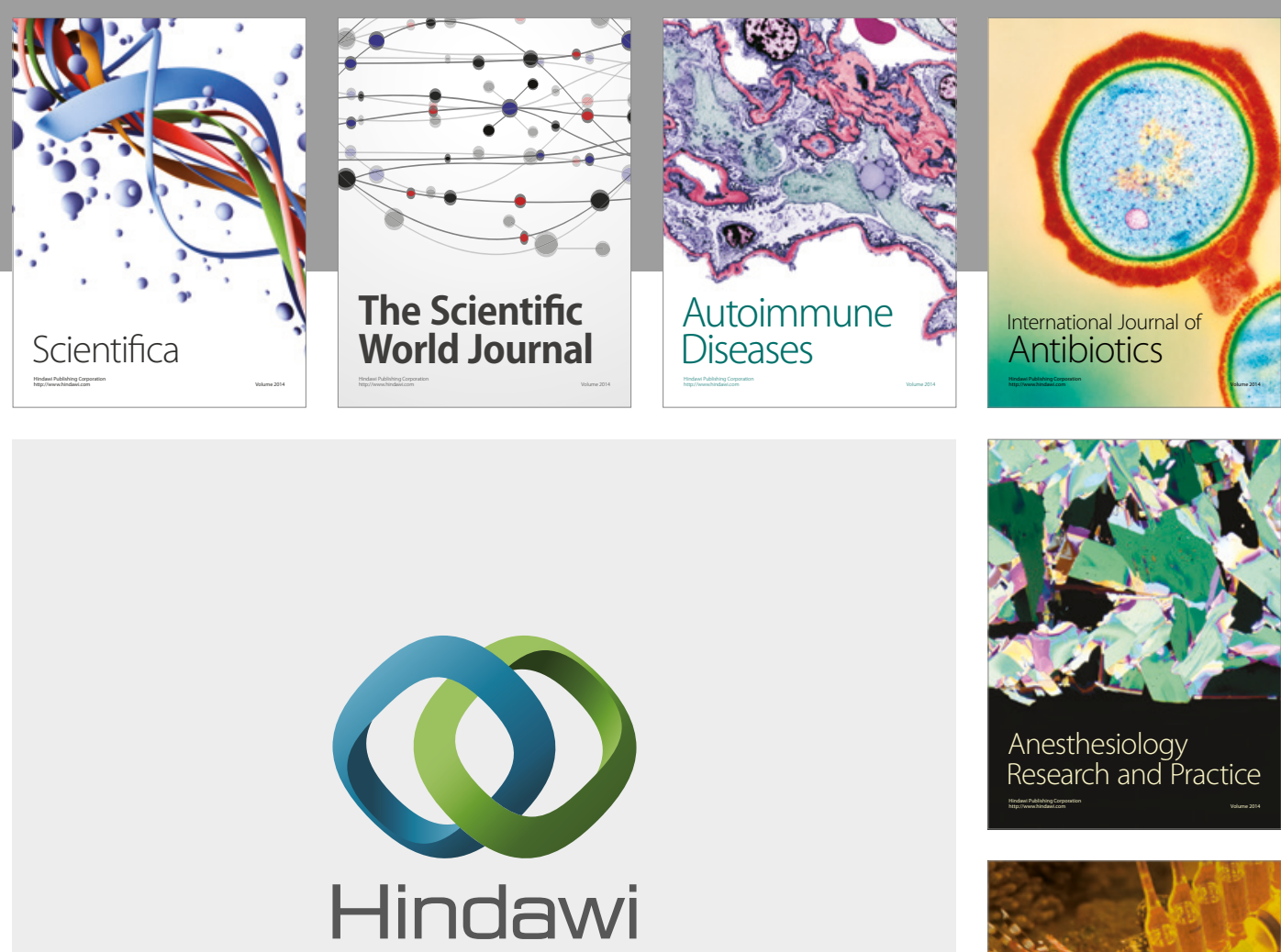

Submit your manuscripts at

https://www.hindawi.com
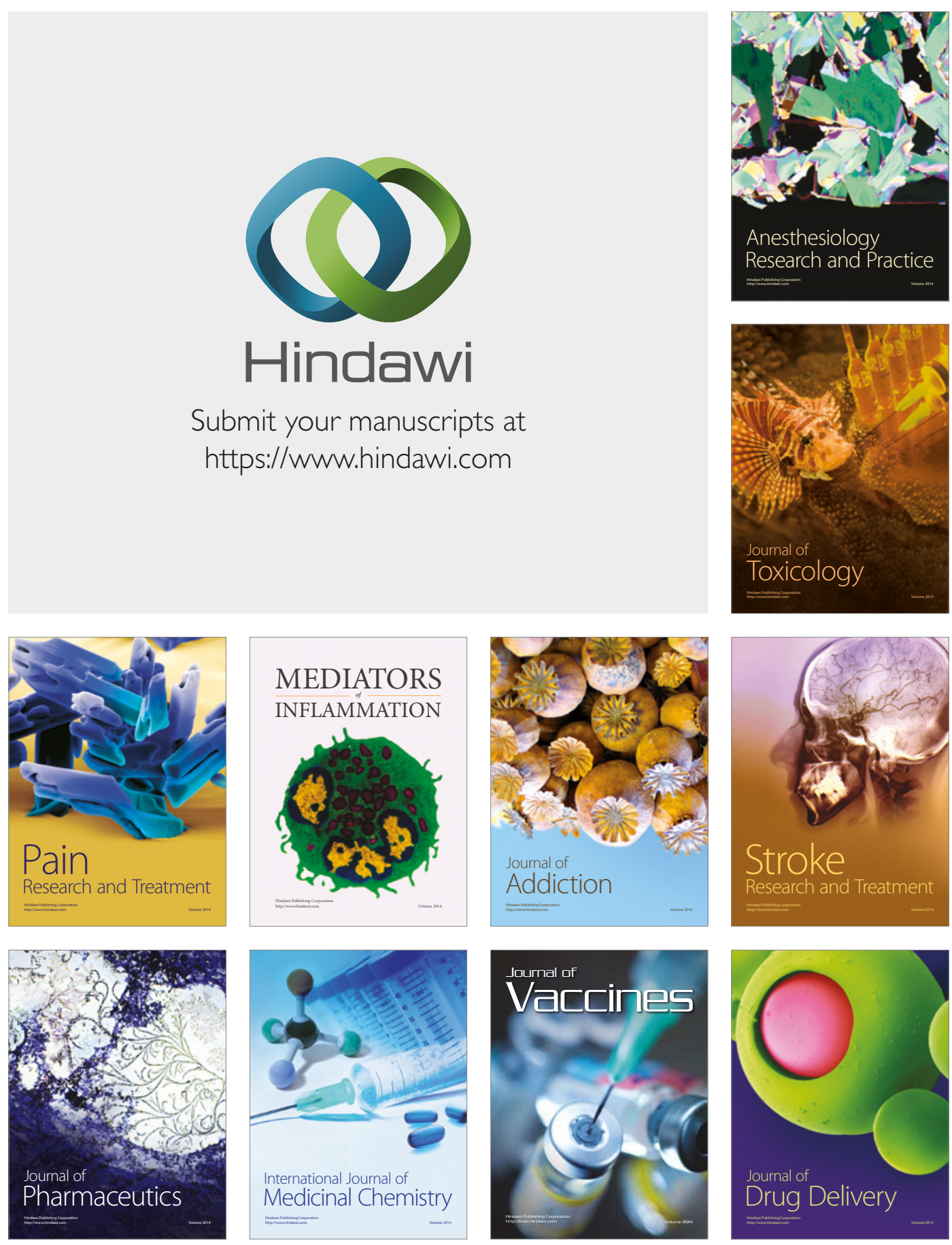